\title{
German Law of Administrative Court Procedure: an Overview
}

\author{
Urs Kramer and Tim Hinrichsen* \\ Institut für Rechtsdidaktik \\ Universität Passau \\ $14 b$ Dr.-Hans-Kapfinger-Str., 94032, Passau, Germany
}

Received 10.05.2015, received in revised form 16.06.2015, accepted 08.08.2015

The authors take the all new Code of Administrative Court Procedure (2015) of the Russian Federation as an occasion to provide a brief overview of the legal situation in Germany. From what the authors learned, both corresponding statutes represent a truly different approach in some areas while they notably concur in others. First, the article presents the general procedural requirements that every action must meet. Consequently, the authors illustrate the major types of action under German law, including the action for rescission and enforcement of administrative acts, the action for rescission of normative acts of the administration, the action for performance or injunction and the action for a declaratory judgment. Every action is accompanied by corresponding summary proceedings that cover urgent situations in what the law thinks of as the most appropriate way. Moreover, German law of administrative court procedure provides for different types of appeals, depending on the nature of the impugned decision. The main purpose of this article is to initiate a mutual discussion on the topic that may improve both sides' understanding of the subject matter.

Keywords: German law, administrative court procedure, administrative act, procedural requirements, types of action, summary proceedings, appeals.

DOI: 10.17516/1997-1370-2015-8-10-2050-2061.

Research area: law.

\section{Introduction}

Until most recently, the administrative court procedure in the Russian Federation was governed by the Code of Civil Procedure (Grazhdanskii protsessual'nyi kodeks Rossiiskoi Federatsii) $)^{1}$ and the Code of Arbitrage Court Procedure (Arbitrazhnyi protsessual'nyi kodeks Rossiiskoi Federatsii) ${ }^{2}$. Only this year, on September 15, 2015, a new Code of Administrative Court Procedure
(Kodeks administrativnogo sudoproizvodstava Rossiiskoi Federatsii) ${ }^{3}$ came into force. The new statute fully replaces the former rules that have often been criticized for not being perfectly suitable for the particularities of administrative disputes. Although disputes are still being heard before ordinary courts and not before special administrative courts, the new approach pays more attention to the fact that administrative legal relationships are based on a system of

(c) Siberian Federal University. All rights reserved

* Corresponding author E-mail address: urs.kramer@uni-passau.de, tim.hinrichsen@uni-passau.de 
subordination rather than the "balance of power" between the parties that is predominant in civil proceedings. This is reflected by a more active role of the court in administrative disputes to even the parties' positions, e.g. by granting the judge the right to gather evidence ex officio. The new codification consists of nine parts and 39 chapters, bringing it to a total of 365 articles. At its core, it provides twelve different types of action, including the action for rescission of normative acts of law (Proizvodstvo po administrativnym delam ob osparivanii normativnykh pravovykh aktov; chapter 21) and of administrative acts and other acts and omissions of the administration (Proizvodstvo po administrativnym delam ob osparivanii reshenii, deistvii [bezdeistviia] organov gosudarstvennoi vlasti, organov mestnogo samoupravleniia, inykh organov, organizatsii, nadelennykh otdel'nymi gosudarstvennymi ili inymi publichnymi polnomochiiami, dolzhnostnykh lits, gosudarstvennykh $i$ munitsipal'nykh sluzhashchikh; chapter 22). Also, article 42 introduces a new "class action" (Obrashchenie v sud gruppy lits s kollektivnym administrativnym iskovym zaiavleniem) allowing 20 or more people sharing the same legal interest to enforce their rights against the state.

In Germany, on the other hand, the current Code of Administrative Court Procedure (Verwaltungsgerichtsordnung) ${ }^{4}$ has been in force since 1960, the history of the administrative jurisdiction itself even dating back to the $19^{\text {th }}$ century. Although the law has since been amended dozens of times, its main decisions have for the most stayed unaltered. The German statute is notably shorter than the Russian one, comprising five parts, 17 chapters and 195 sections in total, a not so little number of the latter having been repealed over the years and only containing a blank space now. Under German law, disputes are heard before three levels of administrative courts with special powers: the first two of them are usually installed on a district (Bezirk)/county (Landkreis) and state (Land) level, respectively, ${ }^{5}$ while the third one, mostly hearing appeals on points of law, is set up as a centralized Federal Administrative Court (Bundesverwaltungsgericht) in the city of Leipzig. There are only six basic types of action, which are generally more abstract and cover more (possible) situations than their Russian counterparts. The German Code of Administrative Court Procedure also contains, among others, the action for rescission of administrative acts (Verwaltungsakte; sec. 42 para. $1^{6}$ ), which have a strong tradition in Germany, and the action for rescission of normative acts that are below the level of a parliamentary statute of a Land (sec. 47).

Yet, the above does not mean that the more mature German set of rules, building upon decades of legislatory and practical experience, is naturally better. The Russian legislator had the opportunity to compensate for the lack of experience by "learning from the best". As the preamble states, several other legal systems have been taken into account drafting the new statute. Thereby Russia could merge foreign legal influences with their own tradition to create an appropriate and effective body of law. This process should be maintained in further developing the law of administrative court procedure not only in the Russian Federation, but also in Germany. The premise of this article is therefore that both the Russian and the German approach can learn from each other in many different ways. The first step to achieve this is an exchange of reliable information. Hence, we hereby want to provide Russian scholars with an overview of the German law perspective, hoping that we can start off a mutual discussion on the subject matter that both sides can ultimately profit from. 


\section{Preliminary remarks}

\subsection{The proceedings}

in German administrative courts

The proceedings are never commenced ex officio, but can only be initiated by the plaintiff by lodging a claim or an application. The plaintiff may at any time alter (sec. 91) or withdraw (sec. 92) his action with the consent of the defendant as long as the judgment has not gained legal force. The parties may further completely or partly deal with the dispute by a judicial settlement (sec. 106). As a general principle, the court usually decides on the basis of an oral hearing that is open to the public, but must not be recorded and/ or broadcasted (sec. 169 Courts Constitution Act [Gerichtsverfassungsgesetz $]^{7}$ ). The scope of the court's decision is bound by the plaintiff's application (sec. 88). On the other hand, the court is obliged to investigate the facts and gather evidence ex officio (sec. 86 para. 1). In administrative courts, disputes are heard before chambers (Kammern) composed of three judges and two honorary or lay judges, all of whom have equal rights in deciding the case. Honorary judges only do not participate when no oral hearing takes place or in the exceptional case that a single judge adjudicates (sec. 5 para. 3). Higherlevel courts do basically not have honorary judges unless otherwise stated by the law of a Land in respect of its Higher Administrative Court (Oberverwaltungsgericht; sec. 9 para. 3).

\subsection{Prospects of success of an action}

Under German law for an action to be successful, it has to meet all the procedural (Zulässigkeit) and substantive (Begründetheit) requirements of the particular type of action. In case of any procedural shortcoming, the action must be dismissed on procedural grounds without a decision on the merits unless otherwise stated by the law, which is only the case in respect of questions of jurisdiction and competence (see below supra 3.1 and 3.2). Only if all procedural requirements are fulfilled, the judge can pass on to an appraisal of the facts of the case. While the main procedural requirements are merely the same or at least very similar for most actions, only differing in certain details, the substantive requirements depend on the particular type of action. Though, generally speaking, for an action against the state to be well founded, the act or omission in question must conflict with corresponding legal rules and violate the plaintiff's rights.

\section{General procedural requirements}

The following are the procedural requirements every action must meet:

\subsection{Recourse to the administrative courts}

For an action to be heard before an administrative court, recourse to the administrative courts must be available. That is basically the case in all public-law disputes. Yet, there are a few exceptions: Constitutional disputes, e.g. actions concerning the compatibility of legislative acts with the German constitution, the Basic Law (Grundgesetz) ${ }^{8}$, although of public law nature, exclusively fall into the jurisdiction of the Federal Constitutional Court (Bundesverfassungsgericht). ${ }^{9}$ Furthermore, some public-law disputes are explicitly withdrawn from the administrative courts in favor of the ordinary courts or special courts such as financial or social courts (cf. sec. 40 para. 1). If an administrative court is addressed in such a case, however, the action must not be dismissed but referred ex officio to the courts that have jurisdiction over it (sec. 17a para. 2 Courts Constitution Act).

\subsection{Jurisdiction of the court}

If recourse to the administrative courts is available, disputes are basically heard before the administrative courts of first instance as long 
as no exceptions apply (sec. 45). The action for rescission of normative acts of the administration $\mathrm{ab}$ initio falls into the jurisdiction of the second level Higher Administrative Courts (sec. 47 para. 1), as do certain other disputes of high significance, e.g. those involving the construction or the operation of power plants (sec. 48). The Federal Administrative Court exclusively hears cases dealing with certain enumerated matters of relevance for the FRG, e.g. if the Federal Intelligence Service (Bundesnachrichtendienst) is involved (sec. 50). Territorially, as a general principle an administrative court has jurisdiction over any act of the administration issued within its district or actions against any defendant whose seat or place of residence lies within its district (sec. 52). As with questions of recourse, if the wrong court is addressed, the claim must not be dismissed but referred to the correct court (sec. 83 in conjunction with sec. 17a para. 2 Courts Constitution Act).

\subsection{Requirements regarding the parties}

In general, an action is not raised against the authority that has committed the act in question, but against the responsible body, which may be the Federation (Bund), a Land or another legal body such as a municipality (sec. 78). ${ }^{10}$ Legally, to take part in the proceedings the plaintiff and the defendant must be either natural persons or legal entities (sec. 61). However, if they are not capable of contracting under German civil law, they may also not effectively perform procedural acts such as lodging an action or arguing in court. This is the case for minors or mentally handicapped persons as well as for legal entities that may not act for themselves. Those parties must at any time be represented by their legal agent (sec. 62). Besides that, the parties may represent themselves in first instance disputes before the administrative courts (sec. 67 para. 1). Further legal representation by an attorney (or a German or European university law professor, respectively) is only mandatory before the Higher Administrative Courts and the Federal Administrative Court (sec. 67 para. 4).

\section{The types of action under German law}

Which type of action is available in a particular situation depends on what the plaintiff wishes to achieve and the subject matter of the dispute (sec. 86 para. 3 , sec. 88 ). The following are the major actions that can be distinguished on that basis and their further procedural and substantive requirements. The rescissory or enforcement action in respect of administrative acts (sec. 42 para. 1) here represents a sort of "prototype" that the law bestows the most attention on. The other actions' requirements can largely be derived from the rescissory or enforcement action.

\subsection{Rescissory or enforcement action 4.1.1. The action}

If an administrative act is at issue, the plaintiff may sue for judicial rescission of that act (Anfechtungsklage) - which usually only occurs if the act places a burden on the plaintiff - or for the judicial enforcement of the issuance of an administrative act by the defendant that would be favorable for the plaintiff (Verpflichtungsklage; sec. 42 para. 1). The latter might follow the refusal of the issuance of the particular act or a mere failure to act on behalf of the defendant. According to sec. 35 Code of Administrative Procedure (Verwaltungsverfahrensgesetz) ${ }^{11}$, a measure is qualified as an administrative act when the following five criteria are met: a. the act in question is of public-law nature (as opposed to acts of private law); $b$. the act is issued by an authority (as opposed to the government of the Federation or a Land, the legislature, the judiciary or a private person); c. the act is intended to cause a legal consequence (as opposed to a mere act); $d$. the act applies to a particular case and addresses 
a single person or a determined or determinable target group (as opposed to an abstract provision of law); e. the act is intended to cause external effects (as opposed to an internal matter). ${ }^{12}$

\subsubsection{Right to sue}

Under German law of administrative court procedure an action may never be brought on behalf of someone else or even the public. There is no actio popularis. For a rescissory action to be permissible the plaintiff therefore must claim a right to sue, i.e. that the administrative act potentially violates his rights (sec. 42 para. 2), while the actual violation is a substantive requirement (see below supra 4.1.5). Though, if a potentially unlawful administrative act addresses the plaintiff and places a burden on him, a violation of his rights is always possible: article 2 para. 1 of the Basic Law contains a general freedom of action (allgemeine Handlungsfreiheit) that represents the basic right to do or not to do whatever you want as long as you do not breach the law. If, therefore, the administrative act was unlawful, it violated that freedom. ${ }^{13}$ A third party, on the other hand, has to claim that a particular provision of law that is intended to protect their rights is potentially infringed. That is because the law normally is not meant to protect third party rights unless otherwise stated. ${ }^{14}$

Similar to the rescissory action, the plaintiff of an enforcement action possesses a right to sue if the refusal of the issuance or the mere non-issuance of the particular act potentially violates his rights (sec. 42 para. 2). That is the case when he claims to be entitled to the issuance of the demanded administrative act, i.e. when the authority might be legally bound to issue that act.

\subsubsection{Preliminary proceedings}

Prior to a rescissory action, the lawfulness and expedience of the administrative act must be reviewed by the administration in preliminary proceedings (sec. 68 para. 1). The same applies mutatis mutandis to the enforcement action if the issuance of the particular act was refused by the authority (sec. 68 para. 2), taking into account that the refusal itself is an administrative act, too. The purpose of the preliminary proceedings is to grant the authority a "second chance" to settle the issue without judicial proceedings. Nonetheless, there are a great number of exceptions to this principle: Some federal statutes allow of instantly filing an action in certain fields of administrative law (cf. sec. 68 para. 1 second sentence). If the defendant is a highest authority of the Federation or a Land, there are also no preliminary proceedings (sec. 68 para. 1 second sentence no. 1). Land law can further define that preliminary proceedings are generally not required in the particular Land (cf. again sec. 68 para. 1 second sentence; this applies to Bavaria in most cases).

If, however, preliminary proceedings are mandatory, the plaintiff must challenge the administrative act within one month of announcement of the act (sec. 70) by raising an objection (Widerspruch; sec. 69). The issuing authority may then remedy the objection and repeal the act (sec. 72). If it does not, the next higher authority - or in some special cases the issuing authority itself - issues a preliminary ruling (Widerspruchsbescheid) that may repeal the original act, amend it or uphold it (sec. 73). In the majority view, even a reformatio in peius is possible if it is fully compliant with the law, i.e. if the higher authority may itself issue such an act and if the plaintiff cannot legitimately rely on the existing state. ${ }^{15}$ If after the preliminary proceedings there is still an administrative act "left" that places a burden on the plaintiff that act - in the shape given by the preliminary ruling - may be impugned in court (sec. 79 para. 1 no.

1). Consequently it is possible that only after the preliminary proceedings the amended act 
negatively affects a third party that had not been concerned before (cf. sec. 79 para. 1 no. 2). That third party may then sue without the initiation of further preliminary proceedings (sec. 68 para. 1 second sentence no. 2).

\subsubsection{Period for filing the action}

Stemming from the overarching principle of legal certainty, some actions must be raised within a certain period of time, dependent on the particular type of action. The rescissory action must be raised within one month of service of the preliminary ruling or, if preliminary proceedings are not required, within one month of announcement of the administrative act (sec. 74 para. 1). After that period has lapsed, the particular act is final and conclusive (bestandskräftig) and may not be challenged, even if it is unlawful. Similarly, the enforcement action may also only be filed within one month if the issuance of the particular act was refused by the administration (sec. 74 para. 2), while otherwise there is no such limitation. The onemonth period is expanded to one year, though, if the authority has wrongfully instructed the plaintiff on the legal remedies available or if such an instruction was not given at all (cf. sec. 58 para. 2 with further exceptions).

Besides that, other than in Russia, in Germany there is no rule on the maximum duration of court proceedings. In the event of a case overload (which is basically the normality), even first instance proceedings may easily take two years or longer, dependent on the subject matter and the complexity of the case. The parties can only file for pecuniary compensation in case of "inadequately" long proceedings (sec. 198 Courts Constitution Act).

\subsubsection{Substantive requirements}

The rescissory action is well founded when the administrative act is incompatible with the law (given that the breached provision itself does not infringe any provision of a higher level) and violates the plaintiff's rights (cf. sec. 113 para. 1). The enforcement action is well founded when the non-issuance of the demanded administrative act contradicts the law and violates the plaintiff'srights (cf. sec. 113 para. 5 first sentence). As mentioned above, that is the case when the authority is bound to issue the act so that the plaintiff is entitled to it. However, in case of administrative discretion in issuing the act the plaintiff may only be entitled to a new discretionary decision of the authority that has to take into account the legal view of the court (unless there is only one lawful decision; cf. sec. 113 para. 5 second sentence). In that case the action is well founded when the previous decision was flawed and thereby violates the plaintiff's rights.

\subsection{Action for performance or injunction}

If one of the above mentioned criteria for an administrative act is not fulfilled, the particular measure is qualified as a mere act or omission of the administration, such as the issuance of a (false) statement or the payment of money. Is this the case, the plaintiff may either sue for performance (Leistungsklage) or an injunction (Unterlassungsklage), the latter by way of exception also being possible as a preliminary action if otherwise unreasonable consequences would occur that cannot be dispelled afterwards. These two types of action are not mentioned explicitly in the Code of Administrative Court Procedure, but their existence can be deduced from several provisions, e.g. sec. 43 para. 2 , sec. 111 and sec. 113 para. 4. In practice, there may often be the need for a joinder of these actions with one pertaining to an administrative act (s. above supra 4.1), e.g. if the plaintiff wishes to challenge an administrative act that imposes a duty of payment on him (rescissory action) 
and concurrently sues for repayment (action for performance; cf. sec. 113 para. 4).

The requirement of a right to sue given for the rescissory and the enforcement action (sec. 42 para. 2) applies mutatis mutandis to the action for performance or injunction. Besides that, there are no further procedural requirements like administrative preliminary proceedings or a certain preclusion period for filing the action. Only the action for a preliminary injunction requires a special interest of the plaintiff that legitimates not waiting for after the act at issue to raise the action, e.g. if the plaintiff would have to commit an administrative offense and pay a fine. The action for performance or injunction is well founded when the plaintiff is legally entitled to the act or omission at issue.

\subsection{Action for rescission}

\section{of normative acts of the administration}

If the plaintiff seeks to question the validity of administrative by-laws, ordinances or regulations, the above mentioned action for rescission of normative acts of the administration (Normenkontrollantrag) before the Higher Administrative Court is applicable (sec. 47). Those normative acts must be below the level of a parliamentary statute of a Land and can be questioned to the extent that Land law provides for such an action (sec. 47 para. 1 no. 2). Only by-laws issued under the Federal Building Code (Baugesetzbuch) $^{16}$, particularly land-use plans, may be challenged according to federal law without a further provision in the law of the respective Land (sec. 47 para. 1 no. 1). In addition to private plaintiffs, the action for rescission of normative acts may also be filed by any authority (sec. 47 para. 2 first sentence), as authorities are bound by normative acts issued by higher-level bodies, too.

As with the actions mentioned above, the plaintiff of an action for rescission of normative acts must claim a right to sue, i.e. a violation of his rights that is present or expectable with reasonable probability (sec. 47 para. 2 first sentence). Only if the plaintiff is an authority, it may already raise an action when the normative act at issue might be unlawful and must be followed but not necessarily also applied by that authority. There is a one-year preclusion period for the action beginning with the official announcement of the normative act (sec. 47 para. 2 first sentence).

The action for rescission of normative acts is well founded when the act in question is unlawful and must therefore be declared null and void (sec. 47 para. 5 second sentence). The latter is only not the case in certain situations under the Federal Building Code whereupon land-use plans might still be upheld in spite of their formal illegality. Although the action procedurally requires a right to sue to preclude plaintiffs that lack a legal interest, an actual violation of the plaintiff's rights is not requisite. That is due to the fact that if the normative act is unlawful it is universally declared null and void by the court.

\subsection{Action for a declaratory judgement}

If not a particular act or omission, but the existence or non-existence of a certain legal relationship of public-law nature is at issue, the plaintiff may file for a declaratory judgement (Feststellungsklage; sec. 43 para. 1). Only concrete questions of law can be subject of such an action, e.g. an access authorization to a facility run by the state. The plaintiff has to claim a legitimate interest in the establishment (sec. 43 para. 1) which might be of legal, economic or fully nonmaterial nature. According to the Federal Administrative Court, the action additionally requires a right to sue, although there does not seem to be a need for this requirement as the legitimate-interest test fulfills the same purpose. ${ }^{17}$ Furthermore, the action for a declaratory judgement is subsidiary to any other relevant action that has further procedural 
requirements (such as a certain preclusion period) which might otherwise be avoided (cf. sec. 43 para. 2). The action for a declaratory judgement is well founded when the legal relationship in question actually is, dependent on the plaintiff's application, existing or non-existing.

\section{Summary proceedings}

German law of administrative court procedure also provides for summary proceedings, the respective type depending on which action is or would be applicable in the main proceedings:

\subsection{Suspensory effect \\ of the rescissory action/ \\ preliminary proceedings}

The rescissory action as well as administrative preliminary proceedings normally suspend the enforcement of the administrative act until the end of the proceedings (sec. 80 para. 1). Yet, in certain situations the law provides for immediate enforcement of the act, e.g. if it is a nondeferrable measure of the police (sec. 80 para. 2 first sentence no. 2). In addition, the authority may, under special circumstances, order the immediate enforcement of the act (Anordnung der sofortigen Vollziehbarkeit) if it thinks that the public interest in the enforcement prevails over the plaintiff's interest in the suspension (sec. 80 para. 2 first sentence no. 4). In these cases, the plaintiff may apply for a judicial order or reinstatement of the suspensory effect of the action/the preliminary proceedings (sec. 80 para. 5). Due to the unclear meaning of the corresponding legal provision (sec. 80 para. 5 second sentence), it is disputed whether the rescissory action must be raised prior to this application..$^{18}$ In any case, the application is only permissible if the main action/application does not obviously lack a procedural requirement.

The application is well founded when either the administrative order of immediate enforcement is unlawful or the applicant's interest in the suspension is more significant than the public interest in the enforcement of the administrative act. To determine this, the court usually summarily looks at the prospects of success of the main action/application.

\subsection{Interim orders against normative acts}

If the action for rescission of normative acts is or would be applicable in the main proceedings, an interim order may suspend the commencement or the further applicability of the act (sec. 47 para. 6), provided that it has already been passed, although it does not necessarily have to have ultimately come into force. The judicial order possesses universal effect and must therefore be limited to absolutely exceptional cases. The application is only well founded when the interim order is necessary to avert serious disadvantages or for other compelling reasons. To determine whether the order must be granted, the court compares the consequences of two thinkable situations: a. the normative act is proven to be lawful, but the interim order was granted; $b$. the normative act is proven to be unlawful, but the interim order was not granted. If the seriousness of the consequences of the latter hypothesis prevails, the court must grant the order.

\subsection{Other interim orders}

In all other cases, the court may, even before the commencement of the action, grant interim orders that can be classified into two subcategories: a. an order to maintain the status quo if an alteration of the existing state may impair a right of the plaintiff (Sicherungsanordnung; sec. 123 para. 1 first sentence); b. an order to (temporarily) grant the plaintiff a right in order to avert major damage or disadvantages that would otherwise occur (Regelungsanordnung; sec. 123 para. 1 second sentence). The application is well founded when the applicant demonstrates to the satisfaction of the court that he is legally entitled 
to the order, i.e. that he would succeed in the main proceedings, and that the case is urgent, i.e. that waiting for the main proceedings is not acceptable.

\section{Appeals}

Under German law of administrative court procedure, the parties may usually appeal twice against a decision of the administrative court. In second instance, one can lodge an appeal on points of fact and law (Berufung; sec. 124), and in third instance, an appeal on points of law only (Revision; sec. 132). Yet, as usual, exceptions to this principle occur. Against rulings of the court that are no judgments, especially decisions in summary proceedings, there is no appeal but a so called complaint (Beschwerde; sec. 146) with the Higher Administrative Court that may not be impugned a second time. It is important to emphasize that recourse to the administrative courts and the jurisdiction of the first instance court must not be questioned on appeal, as the court of appeal is ultimately bound by the initial court's decision to hear the case (sec. 17a para. 5 Courts Constitution Act).

\subsection{Appeal on points of fact and law}

The parties of a first instance dispute, including summoned third parties, are entitled to an appeal on points of fact and law against judgments rendered by the administrative court (sec. 124). The appeal is heard before the Higher Administrative Court and must be admitted by the administrative court or the Higher Administrative Court (cf. sec. 124a). Such an admission is only possible for particular reasons, e.g. in case of serious doubts as to the correctness of the judgment, if the case is especially difficult in terms of fact and/or law or if it is of fundamental significance (sec. 124 para. 2). If admission is not granted, the parties may apply for admission within one month of service of the judgment, the
Higher Administrative Court deciding on the application (sec. 124a para. 4 and 5).

The appeal is permissible if the appellant is aggrieved, i.e. if the administrative court did not fully grant his application on first instance. Summoned third parties, on the other hand, must further claim a violation of their rights or interests. The appeal must be lodged within one month and reasoned within two months of service of the administrative court's judgment (sec. 124a para. 2 and 3). As already mentioned above, legal representation by an attorney or a university law professor is mandatory in second instance proceedings (sec. 67 para. 4). The appeal is well founded when the impugned judgment was wrong, i.e. for an appeal brought by the initial plaintiff: when the action, although dismissed, fulfilled all its procedural requirements and was well founded; and for an appeal by the initial defendant: when the action, although decided in favor of the plaintiff, lacked a mandatory procedural requirement and/or was not well founded.

\subsection{Appeal on points of law}

Any judgment of the Higher Administrative Court, no matter if it is a first- or second-instance decision, may be impugned with an appeal on points of law with the Federal Administrative Court (sec. 132). Against a judgment of the administrative court, an appeal on points of law is only exceptionally permissible in those rare occasions that the appeal on points of fact and law is ruled out by federal law (sec. 135) or as a leapfrog appeal that must be agreed on by both parties and admitted by the administrative court (sec. 134). The appeal requires admission by the Higher Administrative Court or the Federal Administrative Court on grounds of a fundamental significance of the case, a deviation of the impugned judgment from a ruling of a federal court or a procedural shortcoming on 
which the judgment is based (sec. 132 para. 2). As with the appeal on points of fact and law, the parties may apply for admission if it was rejected by the Higher Administrative Court (sec. 133).

The procedural requirements are mostly the same as for the appeal on points of fact and law. The appeal must be lodged within one month and reasoned within two months of service of the judgment of the Higher Administrative Court (sec. 139). Legal representation is required for raising the appeal (sec. 67 para. 4). A party may only appeal if it is aggrieved by the impugned judgment, i.e. if the judgment falls short of the party's application. The appeal on points of law is well founded when the impugned judgment was wrong, provided that the shortcoming is of relevant nature. The Federal Administrative Court is bound by the factual findings of the Higher Administrative Court and may only hear arguments on grounds of a violation of federal law, not Land law (sec. 137).

\subsection{Complaint}

The parties of administrative court proceedings that lead to a decision that is not a judgment are entitled to a complaint with the Higher Administrative Court (sec. 146). The main area of application is rulings in summary proceedings. To accelerate the proceedings, contrary to the appeals available against judgments the complaint therefore does not require a judicial admission. It must be lodged with legal representation within two weeks (sec. 147) and, in case of a complaint against a decision in summary proceedings, reasoned within one month of service of the decision (sec. 146 para. 4).
Similar to appeals, the complaint is well founded when the impugned decision of the administrative court was wrong.

\section{Conclusion}

The approach of the German law of administrative court procedure is to cover as many different situations as possible with comparatively few provisions that only differ inasmuch as necessary. The German law therefore represents a rather homogeneous system that is fairly easy to understand in general but hard to handle in detail. The major difficulty is to determine the final meaning of the often extremely abstract und nebulous wording of the law and to resolve the interdependences of the Code of Administrative Court Procedure with other statutes. It is no surprise that German legal commentaries often fill hundreds of pages. Nonetheless, the general principles of the German law that the authors were hoping to illustrate intelligibly in this article might be an interesting field for a foreign scholar to examine. And who could be more eligible for this task than our esteemed colleagues at the Law Institute of SFU?

\section{Acknowledgments}

The authors wish to congratulate the Law Institute of SFU on its $60^{\text {th }}$ anniversary and look forward to continuing the pleasant and fertile relationship of the University of Passau and the SFU!

They further wish to thank Ms. Tamara Bychkova for providing information on the legal situation in the Russian Federation and for the transliteration and translation of the Russian sources.

\footnotetext{
Code of Civil Procedure (Grazhdanskii protsessual 'nyi kodeks Rossiiskoi Federatsii) of November 14, 2002, No. 138-FZ (in the version of April 6, 2015), SZ RF 2002, No. 46, p. 4532; Law Gazette 2002, No. 220.

2 Code of Arbitrage Court Procedure (Arbitrazhnyi protsessual 'nyi kodeks Rossiiskoi Federatsii) of November 24, 2002, No. 95-FZ (in the version of April 6, 2015), SZ RF 2002, No. 30, p. 3012; Law Gazette 2002, No. 137.

3 Code of Administrative Court Procedure (Kodeks administrativnogo sudoproizvodstava Rossiiskoi Federatsii) of March 8, 2015, No. 21-FZ, SZ RF 2015, No. 10, p. 1391; Law Gazette 2015, No. 49.
} 
4 Code of Administrative Court Procedure (Verwaltungsgerichtsordnung) in the version of the promulgation of March 19, 1991 (Federal Law Gazette 1991 I p. 686), most recently amended by the act of August 7, 2014 (Federal Law Gazette 2014 I p. 890). See references for an English translation of an older version of the act.

5 Not every Land is subdivided into districts and/or counties, mainly because of its particular area and/or for historical reasons. Nonetheless, every Land has at least one first-level and one second-level administrative court.

6 Unless otherwise stated, all sections referred to hereinafter are those of the German Code of Administrative Court Procedure.

7 Courts Constitution Act (Gerichtsverfassungsgesetz) in the version of the promulgation of May 9, 1975 (Federal Law Gazette 1975 I p. 1077), most recently amended by the act of July 12, 2015 (Federal Law Gazette 2015 I p. 925). See references for an English translation of an older version of the act.

8 Basic Law for the Federal Republic of Germany (Grundgesetz für die Bundesrepublik Deutschland) of May 23, 1949 (Federal Law Gazette 1949 I p. 1), most recently amended by the act of December 23, 2014 (Federal Law Gazette 2014 I p. 2438). See references for an English translation of an older version.

9 Though, if a question of constitutional law of a Land is at issue, e.g. the compatibility of a statute of a Land with its constitution, the dispute is heard before the constitutional court of that particular Land.

10 In Germany, the Federation, the Länder, their counties and municipalities are organized as legal persons under public law (juristische Personen des Öffentlichen Rechts) with their own legal personality.

11 Code of Administrative Procedure (Verwaltungsverfahrensgesetz) in the version of the promulgation of January 23, 2003 (Federal Law Gazette 2003 I p. 102), most recently amended by the act of July 25, 2013 (Federal Law Gazette 2013 I p. 2749). No English translation available.

12 Cf. Mitskevich (2008), pp. 116-120.

13 Detterbeck (2014), pp. 559-560.

$14 \quad$ Kramer (2013), pp. 62-63.

15 Cf. Kramer (2013), pp. 74-75; Detterbeck (2014), pp. 569-573; Schoch et al. (2015), sec. 68 annotations 47-53.

16 Federal Building Code (Baugesetzbuch) in the version of the promulgation of September 23, 2004 (Federal Law Gazette 2004 I p. 2414), most recently amended by the act of November 20, 2014 (Federal Law Gazette 2014 I p. 1748). No English translation available.

17 Kramer (2013), pp. 65-66; Detterbeck (2014), p. 592; Schoch et al. (2015), sec. 42 para. 2 annotations 23-32.

18 Kramer (2013), p. 79; Detterbeck (2014), p. 657; Schoch et al. (2015), sec. 80 annotations 460-461.

\section{References}

Basic Law for the Federal Republic of Germany (English translation), including the amendment of July 11, 2012. http://www.gesetze-im-internet.de/englisch_gg/englisch_gg.html

Detterbeck, S. General Administrative Law with Law of Administrative Court Procedure [Allgemeines Verwaltungsrecht mit Verwaltungsprozessrecht]. 12 ${ }^{\text {th }}$ edition, Munich, 2014, pp. 535689.

Eyermann, E (ed.). Code of Administrative Court Procedure, Commentary [Verwaltungsgerichtsordnung, Kommentar]. 14 ${ }^{\text {th }}$ edition, Munich, 2014, $1372 \mathrm{p}$.

German Code of Administrative Court Procedure (English translation), including the amendment of October 10, 2013. http://www.gesetze-im-internet.de/englisch_vwgo/englisch_vwgo.html

German Courts Constitution Act (English translation), including the amendment of July 2, 2013. http://www.gesetze-im-internet.de/englisch_gvg/englisch_gvg.html

Gros' L.A. About the Draft of the Code of Administrative Court Procedure of the Russian Federation [O proekte Kodeksa administrativnogo sudoproizvodstva Rossiiskoi Federatsii]. Ispolnitel 'noe pravo, 2013, pp. 17-19.

Hufen, F. Law of Administrative Court Procedure [Verwaltungsprozessrecht]. $9^{\text {th }}$ edition, Munich, 2013, 644 p.

Il'in A.V. Revisiting the Possibility of the Existence of Administrative Court Procedure As a Procedural Form [K voprosu o vozmozhnosti sushchestvovaniia administrativnogo sudoproizvodstava kak otdel'noi protsessual'noi formy]. Zakon, 2013, pp. 119-129.

Kopp, F.O., Schenke, W.-R. (ed.). Code of Administrative Court Procedure, Commentary [Verwaltungsgerichtsordnung, Kommentar]. 21 ${ }^{\text {st }}$ edition, Munich, 2015, 2036 p.

$$
\text { - } 2060 \text { - }
$$


Kramer, U. General Administrative Law and Law of Administrative Court Procedure [Allgemeines Verwaltungsrecht und Verwaltungsprozessrecht]. $2^{\text {nd }}$ edition, Munich, 2013, pp. 7-102.

Kudriashova E.V. Long-Awaited Code of Administrative Court Procedure of the Russian Federation [Dolgozhdannyi KAS RF], EZH-Iurist, 2015, p. 11.

Mitskevich L.A. Foundations of German Administrative Law: Monograph [Osnovy administrativnogo prava Germanii: Monografiia]. $2^{\text {nd }}$ edition, Krasnoyarsk, 2008, 174 p.

Schenke, W.-R. Law of Administrative Court Procedure [Verwaltungsprozessrecht]. 14 $4^{\text {th }}$ edition, Heidelberg, 409 p.

Schoch, F., Schneider, J.-P., Bier, W. (ed.). Code of Administrative Court Procedure, Commentary [Verwaltungsgerichtsordnung, Kommentar]. $28^{\text {th }}$ edition, Munich, 2015, 5590 p.

Strel'tsova E.G., Tumanov D.A. About the Draft of the Code of Administrative Court Procedure [O proekte kodeksa administrativnogo sudoproizvodstva]. Zakony Rossii: opyt, analiz, praktika, 2013, pp. $49-55$.

\title{
Административное судопроизводство в Германии: краткий обзор
}

\section{Урс Крамер, Тим Хинрихсен}

Институт правовой дидактики

Германия, 94032, Пасcаy, Dr.-Hans-Kapfinger-Str., 14 b

\begin{abstract}
Новый кодекс административного судопроизводства Российской Федерации (2015) используется авторами для краткого обзора правовой ситуачии в Германии. Авторам известно, что соответствующие законь в России и Германии представляют собой действительно различные подходы по некоторым вопросам, в то время как по другим они достаточно схожи. Во-первых, в статье представлены общие процессуальные требования, которым должно отвечать каждое действие. Следовательно, авторы иллюстрируют основные типы исков в соответствии с немецким законодательством, в том числе иски об отмене и исполнении действий административного характера, иски об аннулировании нормативных актов администрации, иски о выполнении или судебном запрете и установительные иски. Каждый иск сопровождается соответствующими сводными протоколами, которые охватывают срочные ситуации, в отночении которых законодательство предполагает соответствующие меры. Кроме того, немеикое законодательство в области административного судопроизводства предусматривает различные типы апеллячионных жалоб, в зависимости от характера оспариваемого решения. Основная иель этой статьи - инициировать совместное обсуждение по теме, что поможет улучшить понимание обеих сторон в данном вопросе.
\end{abstract}

Ключевые слова: немецкое право, административное судопроизводство, административный акт, процессуальные требования, типы исков, упрощенное судопроизводство, апелляиионные жалобы.

Научная специальность: 12.00.00 - юридические науки. 